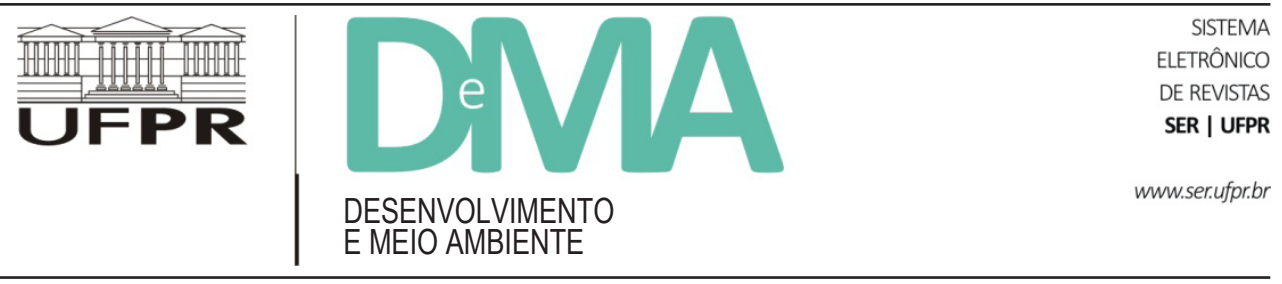

\title{
Meio ambiente e desenvolvimento: imperativos para a pesquisa e a formação. Reflexões em torno do doutorado da UFPR*
}

\author{
Magda ZANONI, Claude RAYNAUT
}

A Universidade Federal do Paraná (UFPR) iniciou em 1990 uma reflexão sobre a criação de um Curso de Doutorado em Meio Ambiente e Desenvolvimento, em colaboração com estabelecimentos franceses de ensino superior (Universidade Paris 7, Universidade de Bordeaux 2, Escola de Arquitetura Paris-La Villette Escola de Altos Estudos em Ciências Sociais). As atividades de ensino iniciaram-se em agosto de 1994. Está destinado a formar professores, pesquisadores, planejadores, agentes de desenvolvimento, profissionais do setor econômico e membros de associações destinadas a operar na área de formação e de implementação de políticas de desenvolvimento sustentado.

Este texto apresenta os fundamentos teóricos e metodológicos a partir dos quais foi elaborado o programa de pesquisa e ensino acima referido. Expõe também, de modo concreto, o contexto social, econômico e político que no Paraná, e, mais amplamente, no Brasil, deu origem a esta iniciativa e permitiu que fosse bem-sucedida.

\section{Do Ecodesenvolvimento ao Desenvolvimento Sustentado}

A partir dos anos 50, o aprofundamento das desigualdades entre países ricos e países pobres motiva a elaboração de diversas estratégias de desenvolvimento.
Nos anos 50, prevaleceram concepções imitativas e quantitativas de desenvolvimento: tratava-se de fato de diminuir a distância entre o Norte e o Sul, através de investimentos financeiros, equipamentos e tecnologias originários dos países industrializados. Esta concepção linear e reducionista do desenvolvimento se dava pela criação de enclaves externos, acentuando as desestruturações entre setores "modernos" e "atrasados".

O decênio seguinte foi marcado pela busca de um desenvolvimento "integrado", no qual foram considerados os conceitos de educação, as dimensões sociais, sanitárias e políticas, sem que se questionasse fundamentalmente o mimetismo. Era o período da "planificação do desenvolvimento". Pouco tempo depois, o conceito de "Nova Ordem Econômica Internacional" faz sua estreia e polariza os grandes debates internacionais sobre as relações Norte-Sul. A ideologia da independência nacional ganha importância.

A problemática do meio ambiente, que tem origem nos países do Norte, expande-se nos anos 70, alimentada pelo debate sobre os limites do crescimento. Nos países da América Latina, esta problemática foi percebida como sendo de natureza conservacionista e neomalthusiana, limitada, no essencial, ao fenômeno do crescimento demográfico e da poluição, e contrária aos esforços de desenvolvimento realizados por esses países desde os

\footnotetext{
* Este texto foi originalmente publicado no Cadernos em Desenvolvimento e Meio Ambiente, volume 1 (1994). Os Cadernos foram criados pelas iniciativa de Magda Zanoni e Claude Raynaut para abrir um debate sobre os fundamentos epistemológicos e metododológicos da interdisciplinaridade no campo ambiental. Neste artigo, em particular, foram discutidos tais pressupostos no caso da fundação do Doutorado em Meio Ambiente e Desenvolvimento que recém havia iniciado sua primeira turma. A tradução foi do professor Dimas Floriani, sociólogo.
} 
anos 30 (industrialização, modernização da agricultura, urbanização, transferência de tecnologia, modelos de consumo e estilos de vida). Neste contexto regional, as preocupações sobre o meio ambiente apareciam como elitistas, deslocadas, enquanto que os esforços de desenvolvimento e de crescimento, nestes países, não tinham atingido sequer seus limites.

O conceito de ecodesenvolvimento introduzido por Maurice Strong, Secretário da Conferência de Stockholm, e amplamente divulgado por Ignacy Sachs, contribuiu para a evolução das ideias sobre os modelos e estilos de desenvolvimento na América Latina. Sachs introduziu a ideia de um "desenvolvimento endógeno e dependente de suas próprias forças, tendo por objetivo responder à problemática da harmonização dos objetivos sociais e econômicos do desenvolvimento com uma gestão ecologicamente prudente dos recursos e do meio" (1980, p. 12). Esta visão superava as abordagens conservacionistas e integrava o meio ambiente na problemática do desenvolvimento.

A difusão do conceito de ecodesenvolvimento foi amplamente assegurada, sobretudo pelo Programa das Nações Unidas para o Meio Ambiente, que o elegeu como um de seus eixos privilegiados de reflexão. $\mathrm{Na}$ França, a Escola de Estudos Superiores em Ciências Sociais e a Casa das Ciências do Homem muniram-se de unidades de pesquisa sobre o desenvolvimento e vários países do Terceiro Mundo, como o México, o Brasil, o Senegal e a Colômbia, formaram também grupos de reflexão sobre o tema.

Em vésperas da Conferência das Nações Unidas sobre o Meio Ambiente e o Desenvolvimento (Rio de Janeiro, 1992), a plataforma Tlatelolco, elaborada pelos representantes oficiais da região América Latina-Caribe, integra, numa perspectiva de desenvolvimento endógeno, a pesquisa de soluções econômicas, sociais e técnicas, com o objetivo de frear o processo de degradação dos recursos naturais atribuído, em parte, aos modelos de desenvolvimento adotados e às limitações impostas pela dívida e os ajustes estruturais derivados desta. O conceito de desenvolvimento se enriquece, então, de uma dimensão humana, com seu corolário de "endogeneidade". O desenvolvimento endógeno delimita, assim, a posição dos atores como criadores de sua própria sociedade e de sua própria cultura.
Os anos 80 viram emergir um novo termo de influência anglo-saxão, o sustainable development, que foi utilizado pela União Internacional para a Conservação da Natureza em sua Estratégia Mundial da Conservação (UICN, 1980).

Em ocasião da Conferência Mundial sobre a Conservação e o Desenvolvimento do IUCN (Ottawa, 1986), P. Jacobs, J. Gardner e D. Munro (1987, p. 1729) falavam do desenvolvimento sustentado e equitativo como novo paradigma, citando como suas prioridades:

- a integração da conservação e do desenvolvimento,

- a satisfação das necessidades humanas fundamentais,

- realização da equidade e da justiça social,

- busca da autodeterminação social e da diversidade cultural,

- manutenção da integridade ecológica.

Em 1987, a Comissão Mundial sobre o Meio Ambiente e o Desenvolvimento retomou em seu relatório, conhecido como "relatório Brundtland", este conceito e propõe a seguinte definição: "desenvolvimento que responde às necessidades do presente sem comprometer as possibilidades das gerações futuras de satisfazer suas próprias necessidades" (Brundtland, 1988: 43). Dois conceitos são inerentes a esta noção: o de "necessidades", sobretudo aquelas dos mais destituídos, e a ideia que a situação de nossas técnicas e da nossa organização social pressiona, até o limite, a capacidade do meio ambiente para responder às necessidades atuais e futuras.

A tradução francesa oficial de sustainable development é développement durable (desenvolvimento sustentado). Entretanto, o termo "durable" (sustentado), contrariamente ao de "sustainable", não exclui que o desenvolvimento possa revelar-se insustentável para a maioria da humanidade. Outras expressões são frequentemente empregadas, tais como "desenvolvimento sustentado", "desenvolvimento viável" ou ainda "desenvolvimento sustentável". Essa diversidade de expressões empregadas é significativa de múltiplas definições agregadas ao termo, tanto na França como em outros lugares. J. Pezzey (1989), através de uma análise bibliográfica, mostra que se há um consenso sobre certos conceitos essenciais do "sustainable development" 
(longo prazo, bem-estar social, solidariedade com as gerações futuras), os autores não deixam de divergir quanto às opções políticas e técnicas: até que ponto a qualidade do meio ambiente e a distância entre ricos e pobres, por exemplo, são fatores importantes do bem-estar social? Em que medida a acumulação de capital e os progressos tecnológicos podem contribuir para reduzir a rapinagem (punções) sobre os recursos naturais?

A inflação de termos e de definições traduz, é bem verdade, uma preocupação que expressa as vias de uma mudança, a partir de conhecimentos disciplinares e de experiências. Entretanto, se um denominador comum é comumente admitido, a dimensão ambiental faz parte integrante do processo de desenvolvimento e não pode ser tratada separadamente. Este conceito representa o eixo central das discussões preparatórias da Conferência das Nações Unidas sobre o Meio Ambiente e o Desenvolvimento da Conferência das ONG do Rio de Janeiro, 1992; o desafio maior deste final de século consiste em inventar, tanto no Norte como no Sul, novos modelos de desenvolvimento.

\section{A necessidade de uma abordagem holística do meio ambiente}

A concepção de um desenvolvimento sustentado é inseparável da gestão dos recursos renováveis. Ela coloca, pois, em primeiro lugar a questão da reprodução das relações entre as sociedades humanas e seu meio ambiente. Ora, a noção de meio ambiente é, por si mesma, difícil de captar por diversos motivos. Seguindo Jollivet e Pavé (1992), podemos explicitar algumas dessas dificuldades:

A noção de meio ambiente é multicêntrica. Isto significa que a noção muda de conteúdo em função do objeto central por meio do qual ela é pensada. De acordo com a visão de um sociólogo, um fisiologista ou um biólogo de populações, o termo poderá ser aplicado de forma alternativa:

- ao contexto familiar, social ou cultural dos indivíduos e dos grupos;

- ao meio bioquímico que influi sobre o funcionamento de um organismo;

- ao quadro natural e antropisado no qual se constitui e evolui uma população de seres vivos.
De uma representação a outra, operam-se deslocamentos de tal maneira que o que era o objeto central numa definição torna-se um elemento do meio ambiente em outro. Uma harmonização das definições é necessária para todo esforço de abordagem metódica.

Ela faz intervir a complexidade. Uma complexidade ligada à amplitude do campo de fenômenos a cobrir, da mesma maneira que à natureza não linear das interações que fazem do meio ambiente um sistema. Os componentes do meio ambiente, inicialmente dissociados numa abordagem do pensamento que conduziu à instauração do recorte disciplinar, devem ser considerados, novamente hoje, em seu conjunto, isto é, em função das múltiplas interações que os unem.

Ela exige uma diversidade de escalas de abordagem. Os processos compreendidos pela noção de meio ambiente se desenvolvem através de múltiplas escalas de espaço e tempo e movimentam uma enorme diversidade de níveis de organização: o local e o global, o instante e o tempo geológico, a molécula e o ecossistema devem, frequentemente, ser levados em conta na elaboração do modelo explicativo. De acordo com o problema colocado e de acordo com a maneira de como é apresentado, privilegia-se diferentes níveis de apreensão - por exemplo, um geomorfólogo, um geógrafo e um agrônomo não abordarão o estudo dos solos no mesmo nível, nem com os mesmos critérios. Não se trata aqui, somente, de diferenças formais, pois, para cada nível de análise, surgem propriedades que não existiam a nível inferior: uma célula não é mesma coisa que a soma de moléculas; uma floresta se diferencia da justaposição das árvores; uma comunidade social não é a simples adição de indivíduos.

A noção de meio ambiente é, pois, inseparável das noções de complexidade e de diversidade. Portanto, se se pretende progredir e não ficar prisioneiro de confrontações entre pontos de vista, conceitos, níveis de apreensão - intrinsecamente válidos em seu conjunto - não se deve proceder a uma definição unificada. Por outro lado, é aconselhável, de maneira mais pragmática, desenvolver alguns princípios básicos que constituem uma plataforma a partir dos quais se viabiliza a comunicação entre os distintos pontos de vista.

O primeiro e sem dúvida o mais fundamental desses princípios - que assume uma posição de axioma básico - é que a compreensão dos processos ambientais 
passa pelo esforço de superar as análises setoriais, limitadas à pesquisa de causalidades lineares e reduzidas a um só nível de apreensão. Por sua própria natureza, os problemas decorrentes do campo ambiental reclamam uma ótica globalizante, holística, que destaca as inter-relações entre fenômenos, as correspondências entre níveis de organização, a imbricação de ligações causais.

É necessário manter a clareza sobre isto. Não se pode pretender que toda pesquisa relativa ao meio ambiente deva desatar, por completo, o nó das inter-relações presentes a partir do problema estudado. Ao contrário, a diversidade do campo contemplado, a multiplicidade das entradas possíveis, o caráter heterogêneo das questões a tratar sugerem uma divisão clara das tarefas, em função dos objetivos precisos e limitados. O importante, e inovador, é a inserção de programas precisos na perspectiva do conjunto que inspira a identificação das temáticas, a formulação dos problemas, e que fornece o quadro de uma progressiva renovação das questões teóricas e metodológicas. É aqui que se situa a abordagem holística.

Levar em conta a globalidade não pode, de forma alguma, ser considerado como um ponto de partida, mas como resultado. Não pode ser contraditória com as abordagens de análises muito especializadas e muito "avançadas", uma vez que estas se inserem numa problemática de conjunto.

\section{As implicações científicas desta abordagem}

Diante das exigências de renovação que impõe a definição de um novo campo de construção do saber, não se pode ficar preso a um discurso geral sobre as formas e os princípios. É absolutamente necessário indagar sobre as práticas científicas a serem implementadas, caso contrário corre-se o perigo de se limitar a simples declarações de intenção.

\section{A necessidade de reformulação de um campo cientifico}

Ao admitir-se a necessidade de uma visão global para analisar os fatos ambientais em toda a diversidade e complexidade de suas implicações - e isso é pré-con- dição de qualquer pretensão para enfrentar um desenvolvimento sustentado - é necessário, ainda, colocar-se de acordo sobre o ponto de vista a partir do qual essa visão será operacionalizada.

Para podermos continuar, parece-nos essencial assegurar que, entre todas as representações possíveis do meio ambiente, sobretudo a que se refere à noção de desenvolvimento, deve colocar no centro de suas preocupações o homem e as sociedades humanas e interrogar-se sobre as condições de sua reprodução e de seu desenvolvimento, o que significa dizer, sobre seu vir a ser. Sob este ângulo, o homem e as sociedades humanas não são mais considerados simplesmente como convidados do meio que habitam - o que permite colocá-los "entre parênteses" quando se quer submeter o meio sob a ótica de uma ciência objetiva. A partir de então, homem e sociedades humanas fazem parte integrante desse meio do qual são, ao mesmo tempo, os sujeitos e os objetos, os atores e os produtos.

Se este pré-requisito é admitido, ele instaura como questão chave interações entre processos naturais, de um lado (físico-químicos e biológicos), e de outro, as condições de funcionamento dos sistemas sociais.

O meio ambiente, assim concebido, inscreve-se numa representação muito ampla que se reúne no interior de um mesmo sistema, englobando - e que pode ser designado de ecosfera - dois subsistemas que interagem e mesmo comungam elementos comuns, porém se organizam segundo propriedades estruturais e dinâmicas diferentes:

A - O sistema Natureza: compreende o conjunto de componentes biológicos e físico-químicos que interagem no interior dos grandes domínios de organização biológica: atmosfera, pedosfera, hidrosfera, geosfera. Este sistema Natureza compreende uma dimensão que, embora fortemente artificializada - a ponto de ser às vezes, como na cidade, um produto direto da ação humana - não deixa de ser um processo da mesma ordem dos meios naturais. Este sistema compreende, certamente, o homem, na perspectiva de organismo vivo - tomado individualmente ou reunido em populações.

B - O sistema Sociedades: que compreende o conjunto de elementos e de processos cuja articulação participa na organização, na reprodução e na evolução das relações sociais e dos fatos culturais. Aqui, as coerências 
que se busca compreender enraízam-se nos processos de produção e de circulação do sentido (representação, valores, normas) que se inscrevem na história e permanecem longamente autônomos em relação às determinações biológicas e físico-químicas. É verdade que nenhuma organização social poderia existir sem uma base material: o próprio corpo dos homens que a compõe; os bens e os objetos cuja produção, circulação e consumo permitem a sua reprodução; as técnicas necessárias à fabricação desses bens e objetos. Mas essa base material somente torna-se parte integrante do sistema Sociedades quando contribui para produzir relações sociais e fatos de cultura, ou enquanto produto dessas relações e desses fatos.

Cada um desses sistemas exige ser analisado em função de suas condições intrínsecas de funcionamento - e é isso que se esforçam em fazer as diferentes disciplinas, no quadro da divisão do trabalho científico que orienta sua distribuição.

O novo campo que se abre - o do meio ambiente considerado do ponto de vista do desenvolvimento sustentado - é o das inter-relações entre sistema Natureza e sistema Sociedades.

Adotar este tipo de representação global implica certas condições na maneira de abordar a questão - que não é nova - das relações Homem/Natureza. Fixemos duas delas:

Quando se analisa o ser humano em sua interação com os ecossistemas, não o consideramos somente como um organismo vivo entre outros, mas, também como o elemento de um sistema social, sem o conhecimento do qual seu comportamento não tem sentido. Admitir isto significa dizer que o imaterial - o ideal, para retomar a formulação de Godelier (1984) - pertence ao real do mesmo modo que os fatos materiais e constitui, no mesmo grau destes, um objeto legítimo e pertinente de análise científica.

Não se separam os projetos de intervenção, relativos a um dos dois sistemas, das consequências que possam vir a ter sobre o outro: não se pode conceber um "desenvolvimento" das sociedades humanas em detrimento do sistema Natureza; da mesma forma, não se pretende proteger os meios naturais às custas de intoleráveis disfunções no sistema Sociedades.

Se se pretende identificar, a partir disto, o campo específico dos estudos ambientais - sem querer substi- tuir o que já fazem, com seus respectivos métodos, as ciências naturais e sociais - nota-se que este campo se localiza na interface dos dois sistemas: no lugar onde nenhuma compreensão é possível sem o apelo simultâneo das propriedades dos dois sistemas. É sob esta forma que a visão holística, mencionada no ponto anterior, ganha sentido e se estrutura.

\section{A referência necessária à interdisciplinaridade}

O enfoque acima definido constitui um desafio científico; exige um trabalho rigoroso de formulação de questões precisas, definição de conceitos, elaboração de métodos.

Colocando o problema desta maneira, observa-se que não há trabalho científico sobre o meio ambiente fora do quadro da interdisciplinaridade.

É necessário, uma vez mais, entrar num acordo sobre o que se entende por interdisciplinaridade. A afirmação da necessária colaboração entre disciplinas no enfoque dos problemas ambientais não é nova: decorre diretamente das exigências da ação. Na realidade, a tomada de consciência da necessidade de uma abordagem interdisciplinar tende a realizar-se fora do campo especulativo. A necessária colaboração entre disciplinas ganha densidade na prática social, cuja finalidade é intervir no real e confrontar-se à complexidade do campo onde atua.

Essa exigência instrumental dificilmente acontece na prática, especialmente no domínio da colaboração entre as ciências naturais, as disciplinas do engenheiro e as ciências do homem. É muito raro verificar que os programas chamados "multidisciplinares" assumam uma forma diferente da justaposição de trabalhos monodisciplinares, cada um deles girando em torno de problemáticas que são valorizadas pelas respectivas comunidades científicas de referência. A "síntese" final aparece então, na melhor das hipóteses, como um exercício de estilo difícil visando oferecer, a posteriori, uma coerência um tanto artificial aos resultados obtidos de forma dispersa. É muito comum defrontar-se, neste domínio, com uma coleção de exposições monodisciplinares dispersas, onde cada uma se esforça para não invadir o território de seus parceiros. Apesar de repetidas tentativas para fazer aparecer o novo, partindo-se da aproximação forçada de 
diferentes especialistas sobre o mesmo terreno, fica cada vez mais claro que a interdisciplinaridade não se decreta, mas que deve ser construída.

Faz sentido falar de interdisciplinaridade, de uma maneira geral e particular no campo do meio ambiente, se existe desde o início identificação de questões reconhecidas como pertinentes pelas disciplinas engajadas; além disto, é necessária a elaboração de uma problemática comum que serve de base para uma divisão do trabalho entre parceiros científicos - cada um explorando, com seus conceitos e métodos, a parte que lhe cabe. É através deste custo que cada um poderá contribuir por elementos de respostas específicos a uma ou várias questões formuladas em comum.

Mais acima, identificamos o campo das pesquisas ambientais que cobrem exclusivamente as questões que se situam na interface do sistema "Natureza" e do sistema "Sociedades". Isto quer dizer que existem outras questões de grande interesse científico, concernentes a cada um desses sistemas considerados autonomamente. Significa dizer, também, que a regra do jogo científico implica, obrigatoriamente, questionamentos cruzados entre as disciplinas (quando se trata de questões ambientais), sendo que nenhuma delas pode pretender sozinha responder aos problemas levantados.

Isso significa afirmar que a abordagem ambiental e interdisciplinar não é relativa aos objetos que se estuda, mas às questões que são colocadas a seu respeito. $\mathrm{O}$ corpo humano é um objeto de pesquisa puramente biológico se for considerado como um organismo vivo. É assunto de reflexão puramente sociológica ou psicológica se for considerado como uma situação de dominação ou um suporte de imagens e de símbolos. Deriva de uma abordagem ambiental, isto é, interdisciplinar, se forem questionados os múltiplos fatores que condicionam sua saúde. Pode-se desenvolver um raciocínio similar, tomando como exemplos o ar, as árvores, o solo.

$O$ essencial reside não no recorte que se faz dos objetos, mas na divisão das questões. Isto compreende duas conclusões:

- a primeira que estabelece cientificamente o campo ambiental e a prática interdisciplinar através da elaboração inicial de uma problemática;

- a segunda que não pode nascer de uma reflexão interna a cada uma das disciplinas, mas deve surgir de um confronto entre as abordagens - confronto surgido, pelo menos na fase inicial, das exigências da prática, uma vez que esta é, por definição, estranha aos recortes entre disciplinas.

\section{As condições para uma colaboração entre as disciplinas}

Um estudo dedicado, a partir de algumas experiências concretas de pesquisa, a uma reflexão sobre a prática de interdisciplinaridade entre Ciências da $\mathrm{Na}$ tureza e Ciências Humanas, ressalta alguns problemas importantes (Dobremez et al., 1990).

A - Os Problemas de Metodologia. Se um acordo mínimo no plano teórico e geral constitui a precondição indispensável ao trabalho interdisciplinar, é na prática concreta da pesquisa que se estabelece o confronto entre as disciplinas: confronto que deve produzir uma colaboração. Para evitar que o programa se reduza a uma simples justaposição de trabalhos, sem ligações recíprocas, como ocorre com frequência, e que acaba produzindo até conflitos entre equipes e pessoas, é indispensável alcançar uma rigorosa organização dos procedimentos da pesquisa coletiva.

Dois eixos desempenham um papel essencial na constituição dessa organização e funcionam como categorias aplicáveis a todo programa.

\section{- O Tempo}

Uma pesquisa se desenrola em um dado período e deve ordenar-se em função deste vetor.

- No plano a conceituação. Quer dizer que ela não se desenvolve como uma pura e simples projeção de um protocolo rígido (contrariamente ao que se produz na pesquisa monodisciplinar, onde a repetição é garantia de rigor); ao contrário, dado o diálogo interdisciplinar e o confronto prático, a problemática tende a enriquecer-se, a diversificar-se e a progredir com o tempo.

- No plano da constituição concreta da pesquisa. O estabelecimento de múltiplas leituras complementares sobre o concreto exige a aplicação de uma estratégia que assuma um itinerário, sob forma de um calendário. 
- Os Níveis de Abordagem

O trabalho coletivo deve organizar-se de maneira que todos compartilhem de um conjunto de hipóteses de trabalho e de objetivos que definam um rumo científico comum. Cada um deve saber o lugar que assume na exploração do problema comum identificado e com quem deve colaborar para tanto; da mesma forma, conhecer as operações concretas nas quais irá encontrar-se no trabalho de campo e em que condições precisas poderá aplicar os instrumentos de sua disciplina (a colaboração de outros exige, às vezes, tolerar certas acomodações nas condições de sua própria prática). O esquema apresentado a seguir é uma tentativa de representar a organização geral de um programa interdisciplinar. Este programa se subdivide verticalmente em vários níveis de abordagem, cada nível se desenvolvendo segundo um vetor temporal. Podemos reconhecer:

- A problemática geral do programa. Ela define: uma temática global; os campos de conhecimentos apropriados, um local (território e objetos de pesquisa); as relações com a demanda social. Esta problemática não é, porém, definitiva, poderá ser desenvolvida e enriquecida no desenrolar do programa.
- Um ou vários programas operacionais. Um programa corresponde a uma parte da problemática, isto é, a uma articulação específica de hipóteses de trabalho e de questões cujo estudo implica uma "missão coletiva" que requer a colaboração de diversas disciplinas. Em decorrência da amplitude e da complexidade do tema envolvido, uma pesquisa interdisciplinar poderá contemplar apenas um ou vários programas. Estes poderão frequentemente se suceder no tempo, em função do enriquecimento da problemática e da emergência de novas questões.

- Operações relativas à pesquisa de campo. É através delas que se executam os programas operacionais. Estes trabalhos serão monodisciplinares, na maioria das vezes, mas poderão também monitorar diversas disciplinas, como nas pesquisas de múltiplos objetivos ou de experimentos em condições reais. Assim, a escolha de escalas de observação incompatíveis com as exigências de uma disciplina bem diferente, ou uma identificação estranha aos objetos de estudo, podem comprometer de maneira definitiva o confronto dos resultados.

Um programa interdisciplinar deve seguir um procedimento caracterizado tanto pela coerência das

\section{ESTRUTURA DE UMA PESQUISA INTERDISCIPLINAR}

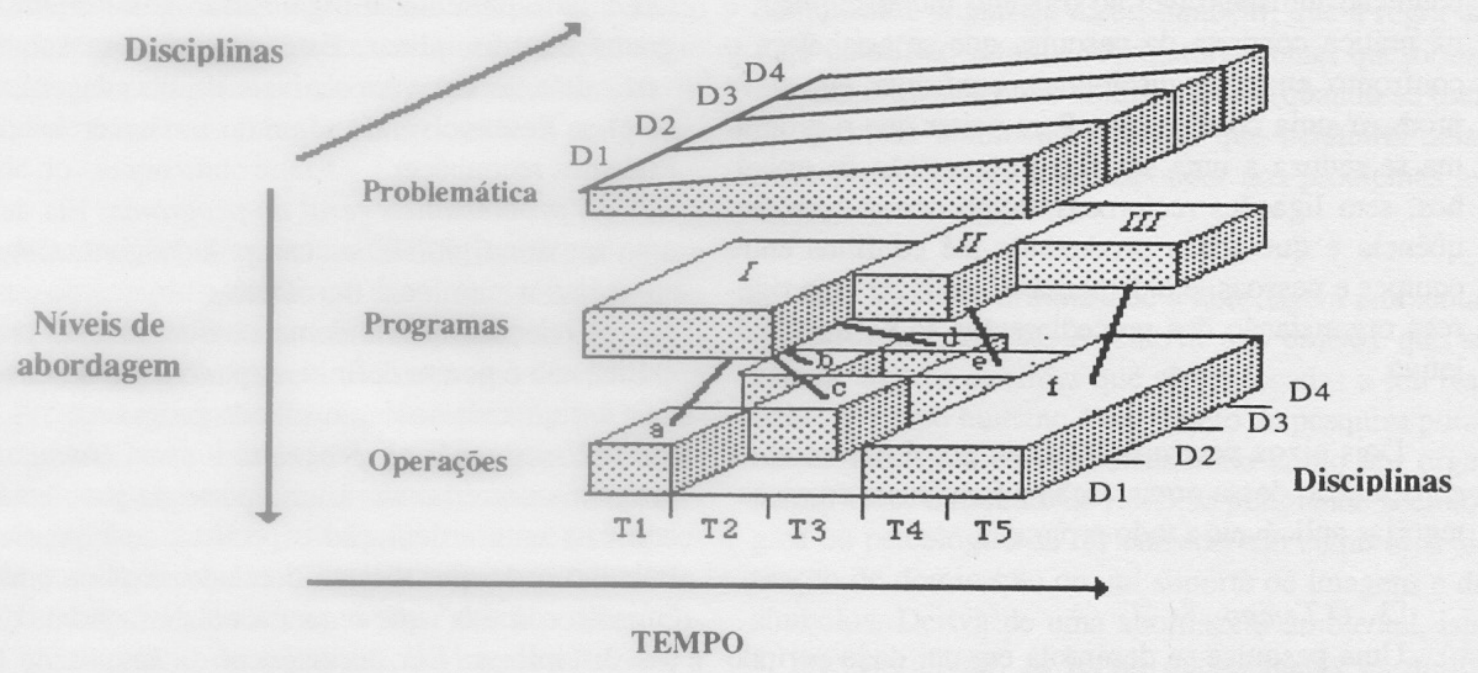


escolhas efetuadas como pelo acerto entre os parceiros, em todos os níveis representados aqui. O rigor não deve, contudo, engendrar a rigidez e o dispositivo elaborado deve funcionar muito mais como um quadro de referência do que um passo a seguir, do qual não se pode distanciar. A problemática de conjunto é necessariamente conduzida para evoluir - e isto acontece sob a pressão da "demanda social". Pode-se colocar em andamento programas operacionais, embora não previstos inicialmente. O mais importante é que qualquer mudança possa ser identificada em função de um quadro de referência global, para que se possa medir as repercussões, tanto do ponto de vista do calendário como da articulação entre os diferentes níveis de abordagem e de colaboração entre as disciplinas.

B - A organização prática do trabalho. A coordenação dos trabalhos e a circulação das informações são problemas típicos de todo trabalho de equipe. Eles se multiplicam nos casos das pesquisas interdisciplinares, devido às diferenças que existem entre as representações, os métodos e as linguagens das diversas disciplinas envolvidas na cooperação.

Por sua vez, a abordagem interdisciplinar é por si portadora de confrontos e de controvérsias. Longe de possuir uma característica acidental, as pesquisas interdisciplinares desempenham um papel heurístico cada vez mais fundamental, à medida que o debate ultrapasse o campo especulativo para alcançar o campo da prática. Nestas condições, as questões de organização prática revestem uma importância particular. O emprego de técnicas correntes de comunicação, reuniões frequentes, circulação de documentos... Entretanto, isto ainda é insuficiente e torna-se indispensável a experiência concreta de um confronto das múltiplas leituras possíveis sobre a mesma realidade. Isto só é possível mediante o encontro no próprio espaço concreto da pesquisa, em determinadas etapas do seu cronograma. Da mesma forma, devem ocorrer operações comuns que obriguem confrontar os detalhes das condições de coleta, de tratamento, formalização e interpretação dos dados empíricos. É só a partir dos confrontos em tomo dos métodos que os debates teóricos podem organizar-se com o máximo de eficácia.

A interdisciplinaridade deve nutrir-se das questões que as disciplinas apresentam umas para as outras; um outro precioso instrumento de reflexão coletiva pode ser constituído por uma rede de questionamentos recíprocos.

Longe de constituir aspecto secundário, a organização prática da pesquisa constitui um aspecto essencial do trabalho interdisciplinar. As dificuldades derivadas desse processo não são suficientemente tomadas em consideração na maioria dos programas de pesquisa.

\section{A necessidade de criar recursos humanos para conduzir esta abordagem}

Depreende-se, pelo que foi dito até aqui, que o sistema de formação existente não responde, até o momento, aos novos desafios teóricos e metodológicos postos pela abordagem interdisciplinar das inter-relações entre o Sistema Natureza e o Sistema Sociedades, o que equivale dizer, ao não atendimento da adoção de um enfoque científico que se adapte às exigências de um enfoque dos problemas ambientais, em ternos de desenvolvimento sustentado.

O recorte atual das formações se faz, ao contrário, em base a uma hiperespecialização que torna, cada vez mais difícil, a comunicação e a colaboração entre os pesquisadores e os práticos das diferentes disciplinas. As competências das quais se pode dispor atualmente, para tratar os problemas concretos de meio ambiente $\mathrm{e}$ de desenvolvimento, são as que se constituíram através trajetórias pessoais, de indivíduos cujas experiência e engajamento permitiram superar o campo restrito da disciplina, na qual se deu a formação inicial de cada um.

Doravante, a necessidade se apresenta na formação específica, capaz de produzir novos perfis de cientistas e de práticos, dotados desde já de uma bagagem teórica e metodológica, permitindo-lhes uma abordagem global, não mais setorial, dos problemas ambientais e de desenvolvimento. É necessário também que esses novos profissionais sejam preparados para dialogar e colaborar concretamente com outras disciplinas, sobre a resolução de questões científicas e práticas que não podem ser resolvidas no interior de apenas uma disciplina.

De que tipos de perfis se necessitam? Não de generalistas pretensiosos de uma competência universal, que pretendem praticar sozinhos a interdisciplinaridade. Necessita-se de especialistas, perfeitamente competentes 
num campo disciplinar preciso (Biólogos, Agrônomos, Médicos, Urbanistas, Engenheiros, Economistas, Geógrafos, Sociólogos, Antropólogos, etc.) mas que recebam uma formação complementar de alto nível que lhes permitam:

- superar o quadro conceitual de sua disciplina de base e conceber os seus limites;

- problematizar da maneira mais ampla possível questões de meio ambiente e de desenvolvimento, em função de uma perspectiva teórica de conjunto, como aquela esboçada mais acima;

- compreender a linguagem, os objetivos científicos e os métodos das outras disciplinas, a fim de poder colaborar com elas.

Retomando a distinção proposta por Vattimo (1992) pode-se dizer que a formação a ser concebida deve possibilitar, a cada um, a descoberta de novos paradigmas, de novos modelos de apreensão do real - segundo uma abordagem que ele qualifica de hermenêutica - no lugar de se contentar de desenvolver o conhecimento e o saber-fazer no interior de apenas um paradigma abordagem que ele designa como epistemológica. Como ainda ele indica, a ideologia dominante da civilização industrial - adotada na maioria dos países em desenvolvimento - superestimou até agora as ciências "duras" e as disciplinas técnicas - percebidas como mais produtivas. Isto é particularmente marcante nas formações existentes no domínio ambiental, no qual os instrumentos de análise do sistema Sociedades são relegadas a segundo plano. A diversificação dos paradigmas passa imperativamente por uma revalorização das ciências humanas, no interior dos cursos de formação - de acordo com o modelo Natureza/Sociedades, sobre o qual deve apoiar-se a abordagem do desenvolvimento sustentado.

Mais adiante, examinaremos as relações que existem entre a aparição do novo campo de reflexão e de pesquisa que tentamos demarcar, assim como a demanda social que aparece como a instigadora. Se uma reflexão global e interdisciplinar sobre as relações entre Sistema Natureza e Sistema Sociedades responde a uma exigência científica, ela está igualmente ligada a exigências práticas. Isto quer dizer que esta nova abordagem não deve permanecer restrita ao meio científico. Ela deve inspirar os práticos do desenvolvimento e da gestão ambiental. Deve, também, oferecer ao público os meios para formular, de maneira rigorosa, as reivindicações que são, por natureza, estranhas ao recorte da realidade em campos científicos mas que têm necessidade de um quadro conceitual para expressar-se com um rigor que lhes propiciará mais consistência.

Ao reclamar uma melhor consideração dos processos sociais na análise dos fatos ambientais, é necessário, contudo, evitar cair na ilusão de que o "maior engajamento das ciências humanas" colocadas a serviço de um enfoque holístico da análise dos fatos ambientais e de desenvolvimento seria suscetível de dar aos atores uma abordagem unificada dos fatos que se tornaria o fundamento científico de um consenso ou o instrumento para a manipulação do real. Não se trata de atribuir ao social um cientismo ampliado para substituir ao que vem atuando, até o presente, sobre uma base exclusivamente técnica. Trata-se de evitar uma tentação "totalitária" que buscaria no enfoque holístico suas justificativas científicas.

De qualquer maneira, a tentativa de assim proceder estaria destinada ao fracasso, uma vez que os conflitos de identidade, os enfrentamentos de valores, as contradições de interesses formam a própria matéria, da qual se alimentam os processos sociais. É impossível fazer a economia desses processos. Não há possibilidade de, apenas pelo conhecimento, alcançar solução única para um problema. Ao contrário, o conhecimento pode permitir esclarecer a identificação das situações naturais, econômicas, sociais de um determinado contexto (é a própria finalidade da pesquisa) e oferecer a todos os parceiros envolvidos os meios de compreender as situações (é o papel que se atribui à formação). Desta maneira, a negociação se torna possível, apoiada em argumentos válidos, tendendo a conciliar da melhor forma possível os interesses e as aspirações das partes em presença. É neste sentido que se pode dizer que os procedimentos democráticos, amparados por um saber compartilhado, podem oferecer uma flexibilidade nova para resolver os problemas de meio ambiente e de desenvolvimento - contribuindo desta maneira, mesmo que de forma imperfeita, à busca de um equilíbrio sustentado nas relações entre o Sistema Natureza e o Sistema Sociedades.

Em termos de formação, um tal projeto significa que os objetivos propostos deverão desdobrar-se em diversos níveis: 
- Do mundo científico e técnico que deverá analisar os problemas e explorar os diferentes meios que estão disponíveis para tanto.

- Dos responsáveis políticos e administrativos que deverão ser competentes para enunciar as questões práticas, de forma cientificamente adequada.

- Dos diferentes parceiros sociais que deverão formular suas reivindicações, estabelecendo a ligação entre suas aspirações e suas necessidades imediatas, por um lado, e as imposições de longo prazo de um desenvolvimento sustentado, por outro.

\section{Problemas institucionais e sociais oriundos da dinâmica desses objetivos}

\section{Potencialidades e resistências dos sistemas de ensino e de pesquisa}

Acabamos de ver que a interdisciplinaridade se revela como uma exigência científica e uma necessidade prática, desde que se queira tratar de problemas de meio ambiente e de desenvolvimento, segundo uma perspectiva não compartimentada.

A estrutura atual da pesquisa e da formação deve constituir a base para a implementação deste novo enfoque. De fato, a interdisciplinaridade só será construída a partir de disciplinas solidamente estabelecidas do ponto de vista teórico e metodológico. É nas universidades e nos centros de pesquisa que se encontram atualmente os polos de excelência onde se realizam os trabalhos avançados e onde a pesquisa de alto nível encontra abrigo. É com este potencial que se deve trabalhar, dada a garantia de qualidade que representa para a produção científica, sem a qual é tarefa vã pretender produzir algo inovador.

A pesquisa e a formação interdisciplinares, necessárias à implementação de uma abordagem de desenvolvimento sustentado, devem constituir-se a partir daquilo que existe de melhor em cada uma das disciplinas envolvidas, ao contrário daquilo que poderia considerar-se como a forma de um "menor denominador comum" científico.

Mesmo se uma tal exigência parece ser amplamente aceita, no plano dos princípios, isto não significa que sua implementação seja tranquila, sobretudo quando se trata de fazer com que homens e instituições colaborem entre si. Diversos tipos de dificuldades aparecem no plano da cooperação científica entre disciplinas. Abordaremos duas que nos parecem fundamentais.

A - Os territórios de poder. Cada disciplina desenvolveu uma imagem de si própria, a partir da qual se reconhece e interage com as comunidades dos cientistas. Ela tende a fazer funcionar seu sistema de representação científica como uma escala de valor: aceitar que outros olhares possam ter idêntico valor que o seu, quando analisa seu objeto de estudo, pode parecer colocar em xeque sua própria identidade; isto, sem considerar os aspectos defensivos que uma tal atitude pode desencadear. Dito de maneira mais direta, construíram-se territórios de poder sobre os territórios intelectuais, com as relações interpessoais de dominação e de dependência que os viabilizam e com os ganhos materiais e simbólicos que isto representa. Um professor ou um pesquisador que batalhou durante toda sua carreira para chegar a criar o departamento ou o laboratório, símbolos emblemáticos de seu sucesso científico, que exerce sua tutela sobre estudantes e colegas mais jovens e menos brilhantes, apresentará sérias resistências em relação a uma nova postura científica que coloca em risco a lógica de seu procedimento. Por trás dos debates epistemológicos, nota-se essas resistências mais do que qualquer outra coisa.

B - Os procedimentos de avaliação. As comunidades científicas regulam seu funcionamento - consagram as filiações, sancionam as hierarquias - com base em procedimentos de avaliação que cada disciplina estabeleceu e que constituem a garantia do valor do trabalho intelectual consumado. No caso da formação, vale o controle da aquisição reconhecida de conhecimentos; no caso da pesquisa, legitimação da produção científica original. A produção escrita deve satisfazer critérios que traduzam a qualidade - publicação em revistas com comitês editoriais, frequência de citações, etc. Tais procedimentos constituem a forma pela qual a produção científica adquire reconhecimento. A reprodutibilidade das observações num contexto onde os parâmetros são rigorosamente controlados é uma exigência fundamental das ciências explicativas.

Esses diferentes critérios estão longe de serem satisfeitos, no âmbito de nossa atuação. A complexidade 
e a especificidade das situações analisadas torna a estrita reprodução das observações mais difícil ainda. $\mathrm{O}$ aspecto prático dos problemas a resolver faz com que os resultados sejam mais objeto de um uso social do que um caso para publicação. A novidade das questões colocadas e dos métodos utilizados tornam precárias as condições usuais de referência e de legitimação - como as que aparecem em revistas interdisciplinares reconhecidas, no âmbito internacional, por exemplo - comprometendo assim a garantia do valor do trabalho realizado, segundo esses critérios.

Todos esses obstáculos, que remetem a verdadeiros problemas científicos, fazem com que nenhum indivíduo, tomado isoladamente, possa escolher uma prática interdisciplinar inovadora, sem colocar em perigo seu futuro profissional. Apenas os cientistas, cuja posição institucional está assegurada, poderiam correr este risco: isto, porém, pôde contrariar as formas de interesse estabelecidas e usuais.

Feitas essas constatações, pode-se chegar à conclusão de que para sair do impasse, o desafio deve ser tomado a nível institucional; igualmente, deve-se pensar no estabelecimento de um quadro específico de legitimação do trabalho científico interdisciplinar - seja de maneira provisória até que um novo campo se estruture e que uma nova comunidade se forme, promovendo seus próprios procedimentos de reconhecimento, de avaliação e de validação. Não se trata de provocar a interdisciplinaridade através de uma prática voluntarista, mas de oferecer as condições institucionais que permitam o exercício de uma vontade científica já em andamento.

\section{A relação com a demanda social}

Quaisquer que sejam suas origens - mesmo que os cientistas tenham contribuído, algumas vezes, para a tomada de consciência - os problemas ligados ao meio ambiente revestem, doravante, uma dimensão social que é exterior à ciência. Correspondem a situações cujas implicações escapam, em grande medida, do campo das preocupações científicas. São essas circunstâncias e suas manifestações coletivas que correspondem ao que se designa sob o termo de demanda social. É uma noção vaga que pode ser aplicada tanto a formas institucionalizadas, expressas através da ação dos poderes públicos, como a manifestações mais informais que revelam as aspirações ou as reivindicações mais ou menos organizadas e contraditórias de categorias e de comunidades sociais.

Em ambos casos, algumas questões são colocadas à ciência. Isto ocorre nos casos de elaboração de relatórios (necessários sobretudo para o estabelecimento de normas) ou na expectativa de soluções para problemas mais concretos. Num caso como no outro, coloca-se a questão da produção do saber (tarefa da pesquisa) e da transmissão deste saber em diferentes níveis, visando torná-lo operacional. A Universidade, o lugar por excelência da produção e da transmissão do saber, não poderia permanecer insensível às demandas que continuamente lhes são dirigidas.

A Universidade não pode limitar-se, apenas, a evocar ritualisticamente a necessidade de "sair de sua torre de marfim" e de levar em conta a demanda social. Não existe apenas uma, porém múltiplas demandas sociais que refletem as contradições, os corporativismos e os conflitos que atravessam a sociedade. O Estado e seus organismos são emissores de uma demanda - podendo expressar sua legitimidade à medida que a mesma venha revestida de forma democrática Da mesma maneira ocorre com a sociedade civil, com sua divisão de interesses, seus confrontos e solidariedades. Cedo ou tarde, o engajamento das instituições universitárias, diante das diversas demandas que lhes são dirigidas, implicará escolhas e tomadas de posições que transcendem os critérios exclusivamente científicos.

Para reduzir tais distorções, um esforço relevante deve ser realizado a fim de contemplar as reivindicações populares, as prioridades políticas e as exigências econômicas, para que ganhem sentido no campo científico. É verdade que nem todos os parceiros potenciais dispõem dos mesmos recursos para realizar esse esforço: as elites do poder e da economia dispõem de formação e de apoios técnicos que lhes facilitam o trabalho; a mesma coisa não ocorre com os Movimentos Populares e, às vezes, com as ONGs.

A - O contexto geral das relações entre as universidades e a demanda social no Brasil. Numa conjuntura de crise econômica e política, sobretudo no contexto de crise de identidade do Estado, a demanda social é veiculada principalmente pelas Organizações Não Governamentais 
e pelos Movimentos Associativos das mais diversas naturezas. Estes se esforçam para suprir a incapacidade dos organismos públicos, no que se refere à formulação das demandas e dos meios adequados para seu atendimento. É muito comum, a nível local, as ONGs e as Associações substituírem o Estado nas ações relativas à saúde, educação, habitação, desenvolvimento agrícola. Neste contexto, a Universidade está cada vez mais voltada para colaborar com as ONG e os Movimentos Associativos que canalizam e organizam a demanda social.

Esta questão foi diretamente abordada no Fórum Rio 92, no painel Universidades, Movimentos Sociais, Organizações Não Governamentais. Citamos aqui alguns dos pontos enfatizados naquela ocasião.

- As relações da universidade com a sociedade civil estão condicionadas pelo papel que esta instituição desempenha no conjunto das relações sociais e políticas. A universidade brasileira, ao longo de sua história, alinhou-se com as elites do Estado, das empresas e do capital. Contribuiu diretamente para a consolidação do modelo do atual desenvolvimento, que exclui milhões de brasileiros dos benefícios do progresso. No contexto da crise atual, espera-se mais do que nunca que a Universidade possa desempenhar sua função de prestadora de serviço público e que se dedique a responder às necessidades da maioria da população, em termos de produção e transmissão de conhecimento.

- A relação entre as universidades e as ONGs está subordinada a uma avaliação ética. As ONGs exigem conhecimento, mas elas também estão, habilitadas a oferecê-lo. A relação deve estabelecer-se com base na troca e não sob a forma de prestação de serviços. Mesmo que esses contatos se devam, na maioria das vezes, às relações individuais fortemente personalizadas (entre tais pesquisadores e tais responsáveis das ONGs, por exemplo), as relações entre universidades e ONGs ou Movimentos Populares devem encontrar um apoio institucional. As universidades brasileiras devem abrir-se, sob forma de convênio, com sindicatos, organizações sociais, religiosas, esportivas etc. É a este título que poderão sobreviver às tentativas de privatização - quando não é o caso de sucateamento - diante das quais se expõem atualmente.

- A contribuição das universidades pode assumir múltiplas formas: estudos junto a movimentos populares; formação de dirigentes e de militantes de movimentos; avaliação crítica das ações de desenvolvimento impostas pelas autoridades; produção de conhecimento para responder a problemas específicos; difusão de informação científica através de meios acessíveis.

Apesar da vontade expressa por ambas as partes, visando a uma cooperação, algumas dificuldades apareceram, dentre as quais se pode citar algumas:

- Uma mistura de papéis e uma confusão de relações. Tanto mais as ONGs estão próximas da realidade social, mais elas sentem dificuldades de se relacionar com a universidade. De parte de seus quadros, com os quais os universitários estão geralmente em contato, é comum ocorrer uma confusão entre posições militantes - inspiradas pela obtenção de relações de forças favoráveis no plano das lutas - e a preocupação de rigor e de prudência que guia o discurso científico. Esta mistura de papéis produz, em muitos casos, uma confusão nas relações. Isto é tanto mais verdadeiro na, medida em que os movimentos sociais têm uma dimensão política; seus quadros militantes participam às vezes de tendências heterogêneas em problemáticas variadas. Isto pode tornar a cooperação difícil com as equipes universitárias, porque estas necessitam de objetivos científicos delimitados para elaborar sua problemática.

- $\mathrm{O}$ acesso ao saber e ao conhecimento mútuo. A demanda social, tal como chega às equipes científicas, é geralmente inspirada por situações vivenciadas, mas é frequentemente formulada de uma maneira que a torna dificilmente utilizável, como tal, num programa de pesquisa. Uma grande parte dos movimentos populares desconhece a produção universitária, pois esta é produzida sob uma forma que a torna inacessível aos não-especialistas e porque a seus quadros faltam noções de base que lhes permitam problematizar, em termos científicos, as dificuldades concretas com as quais se confrontam. Inversamente, o meio universitário está muitas vezes divorciado da realidade vivida por seus interlocutores e não é sempre que se pode fazer a junção entre o saber construído e as necessidades daqueles que se dirigem à universidade. Para que a colaboração se tome frutífera, é indispensável estabelecer condições de interconhecimento, quer dizer, uma troca de saberes. Essas condições estão distantes de se realizarem, daí a emergência de incompreensões e de dificuldades. 
- A concorrência na obtenção de financiamentos. A divergência de interesses institucionais pode ser acompanhada de rivalidades mais palpáveis, na esfera da busca de financiamentos. Os orçamentos das universidades se reduzem cada vez mais, o que não lhes permitem sequer garantir as condições mínimas de sobrevivência, obrigando-as a buscar fontes externas de financiamento - sobretudo das agências bilaterais ou multilaterais de auxílio - para onde as ONGs se dirigem para buscar financiamentos. Disto resulta uma situação de concorrência que pode estar na origem das relações tensas.

- Os diferentes interesses institucionais. Os interesses de instituições de natureza diferente nem sempre convergem. Embora a produção do conhecimento não constitua o principal objetivo das $\mathrm{ONG}$, algumas delas são levadas a realizar pesquisas. Desta maneira, elas entram neste campo, em concorrência com as universidades, abordando a pesquisa em condições diferentes. As universidades são instituições cuja sobrevivência está praticamente assegurada, independentemente de sua produção imediata de conhecimento. Para reproduzir-se, as ONGs e as Associações devem, ao contrário, prover constantemente o fluxo de financiamento e de adesão para assegurar sua sobrevivência. Devem, portanto, provar sua eficiência aos olhos dos fornecedores de dinheiro e de seus militantes. Estas distintas posições produzem, desde o início, atitudes divergentes no plano da pesquisa e da produção do conhecimento. Assim, observa-se, do lado das ONGs, uma valorização excessiva às vezes, do curto prazo e da aplicabilidade da pesquisa; enquanto que no meio universitário, perde-se muitas vezes de vista a noção de utilidade social da produção científica, em benefício da busca de reconhecimento por parte de uma pequena comunidade de pares. Estas perspectivas divergentes tornam frequentemente a colaboração difícil.

Não se deve perder de vista, por sua vez, que uma formulação científica adequada só é possível se o marco conceitual, teórico e metodológico, existe para ser cumprido. Vimos mais acima, em relação ao meio ambiente, que nos encontramos atualmente numa fase de construção do campo científico que exige ajustes, redefinições, tentativas que nem sempre facilitam a problematização científica das questões concretas que emergem da sociedade civil ou das estruturas do Estado. Esta constatação deve confirmar a convicção de que a elaboração de instrumentos eficazes deve ocorrer simultaneamente com a conduta de uma reflexão científica aprofundada.

B - Algumas experiências brasileiras de resposta universitária à demanda social. No Brasil, os problemas ambientais encontram suas raízes, em grande medida, nos processos de industrialização e de urbanização acelerados que o país conheceu a partir dos anos 40. No entanto, a expressão de uma tomada de consciência sobre esses temas apareceu bem mais tarde, provocada pelo aspecto claramente destruidor do modelo econômico, adotado durante o período da ditadura militar (19641985), na conjuntura eufórica do "milagre brasileiro".

Essa tomada de consciência passou por diferentes etapas desde 1974: da proteção da natureza à sensibilização crescente dos indivíduos e das populações à destruição dos recursos naturais, até chegar hoje à adoção de uma nova ética do desenvolvimento que passa pela busca de um modelo alternativo ao produtivismo e pela preocupação de uma qualidade de vida satisfatória para o conjunto da população.

Esta evolução é o resultado complexo do acúmulo de experiências locais ou regionais e da interação de fatores econômicos, sociais, políticos e ecológicos específicos de cada situação local. É desta maneira que os movimentos sociais, oriundos dos conflitos agudos provocados pela explosão da refinaria de petróleo em Cubatão, em São Paulo, pela construção da barragem de Itaipu no Paraná e de Tucuruí na Amazônia assumiram uma dimensão nacional, além de servir de exemplo para outros movimentos. Ademais, nos Estados diretamente envolvidos, os movimentos contribuíram para uma importante mobilização de certas equipes do governo, de universitários e de agentes do movimento associativo. É em torno de tais temas concretos que se erigiu a cooperação entre os meios científicos e as diferentes esferas da demanda social.

Neste contexto geral, numerosos intelectuais e cientistas se engajaram para colocar suas competências a serviço dessas lutas. Diversos universitários brasileiros estabeleceram trocas com ONGs e com diferentes movimentos sociais, em ocasião de conflitos relativos a problemas ambientais. Dentre a multiplicidade de exemplos que se pode oferecer dessa colaboração, retivemos alguns particularmente ilustrativos. 
- Movimentos oriundos dos impactos sociais e ambientais das grandes barragens. Os movimentos sociais nasceram em resposta aos múltiplos impactos desestabilizadores das grandes obras de barragens: desestruturação das atividades econômicas preexistentes, crescimento desordenado da população, expulsão dos agricultores - cuja consequência foi a marginalização e o desemprego -, degradação ambiental. Este foi o caso da realização das grandes barragens do Alto Uruguai (Estado do Rio Grande do Sul). O Instituto de Planejamento Urbano e Regional (IPUR) da Universidade Federal do Rio de Janeiro foi solicitado para prestar apoio ao Movimento dos Agricultores, vítimas daquelas barragens. Esta demanda foi feita através de uma ONG: o Centro Ecumênico de Documentação e Informação (CEDI).

Uma ligação institucional, sob forma de acordo oficial, foi estabeleci da entre o CEDI e a Universidade Federal do Rio de Janeiro. Seu objetivo era o apoio técnico e de formação - com a edição de textos didáticos sobre as políticas energéticas, sobre as políticas e as legislações relativas ao meio ambiente, sobre o desenvolvimento regional e as barragens. Uma colaboração direta teve lugar também com o Movimento dos Agricultores, vítimas das barragens: contribuição para a reconstituição da história do movimento; análise da documentação sobre os estudos oficiais dos impactos; simulação do funcionamento das auditorias públicas.

O engajamento desta instituição universitária foi motivado pelo interesse ligado ao campo temático e pelas competências que podia colocar a serviço deste problema. As pesquisas engajadas, preocupadas em responder aos critérios de rigor científico, possuíam uma dimensão política: seu objetivo era formular um saber que pudesse ser transmitido aos movimentos populares e sobre o qual pudessem apoiar suas práticas reivindicatórias.

Encontra-se nisto a ilustração perfeita de uma produção científica que indaga sobre sua utilidade social e escolhe claramente seus parceiros entre os protagonistas emergentes das lutas ambientais - protagonistas que podem, cada um deles, pretender formular uma demanda social! O confronto com as empresas elétricas representou um grande desafio para os movimentos populares, construídos em tomo da resistência à implantação autoritária das grandes barragens. Diante de um discurso que se apoiava em argumentos técnicos e econômicos apresentados como inevitáveis, era um empreendimento perigoso querer forjar uma identidade comunitária cujo objetivo poderia aparecer oposto ao progresso. $\mathrm{O}$ apoio trazido pelos cientistas foi, pois, determinante nesta caminhada. Permitiu colocar o debate num outro nível daquele que os partidários das barragens buscavam isolar e também reconsiderar a construção destas à luz de uma análise crítica do modelo energético brasileiro.

- As reservas florestais extrativas da Amazônia. A partir dos anos 1971/1975, o Estado amazônico do Acre conheceu uma verdadeira "febre de terras" - para satisfazer ao desenvolvimento explosivo da pecuária extensiva. Imensos espaços foram assim desmatados. Expulsos de seus territórios de exploração da Hevea, os seringueiros empreenderam diversas formas de resistência. Organizaram-se em movimento, sob a direção do Conselho Nacional dos Seringueiros que, muito rapidamente, anexaram à sua luta reivindicatória propostas de desenvolvimento e de proteção dos recursos naturais: a principal delas foi a criação de reservas de extração. Estas representam a seus olhos "a reforma agrária dos seringueiros". Consistem em atribuir terras da União - oriundas da tutela do Estado Federal - sob forma de concessões de uso, para seringueiros organizados em cooperativas e em associações. Estas reservas são concebidas fora de toda atribuição de títulos individuais de propriedade - mantendo-se a cultura e as formas tradicionais de organização e de trabalho dos seringueiros. O objetivo é assegurar simultaneamente a conservação da floresta e o desenvolvimento das atividades econômicas, com o auxílio de tecnologias apropriadas. Estas reservas são concebidas como uma alternativa às formas de exploração predatória da floresta amazônica. Estas reivindicações foram reconhecidas pelo Governo e um decreto definiu a existência e as condições de sua criação em 1990.

A implantação de um tal projeto implica um trabalho de pesquisa científica e técnica que possa permitir lançar as bases de uma exploração sustentável dos recursos florestais e de um desenvolvimento das comunidades de seringueiros. Um convênio foi firmado para esta finalidade entre a Universidade Federal do Acre e o Conselho Nacional dos Seringueiros. A ação dos pesquisadores e dos professores se exerce simultaneamente na esfera da formação e da pesquisa de campo, com uma particular 
exigência, qual seja, a de apresentar de maneira acessível e prática os conhecimentos produzidos, colocando-os ao alcance da população que possui um baixo nível de escolaridade. Dentre as ações conduzidas pela Universidade do Acre, citam-se:

- Uma coordenação dos trabalhos de campo em 8 zonas de reserva extrativista do Vale do Acre.

- A participação de estudantes estagiários nos trabalhos de pesquisa de campo.

- A formação de seringueiros em técnicas de enquete sobre seus sistemas de produção agro-florestais e suas condições de vida.

- A fixação das populações rurais nos assentamentos da reforma agrária. No quadro do processo de reforma agrária, as atribuições de terras - assentamentos - foram previstas em benefício dos camponeses sem terra. É em grande parte o resultado das lutas conduzidas pelo Movimento dos Trabalhadores Sem Terra, bastante desenvolvido no Sul do Brasil. No Paraná, durante o período 1983-1985, a Secretaria de Estado da Agricultura envolveu agrônomos, sociólogos, economistas e diversos serviços do Estado no apoio aos assentamentos. Um convênio foi assinado, para esta finalidade, entre a Universidade Federal e o Departamento de Economia Rural da Secretaria de Estado da Agricultura. Os objetivos eram os seguintes:

- A elaboração de diagnósticos nas áreas agrícola e econômica.

- A troca de informações entre os movimentos sociais e os serviços do Estado.

- A colaboração nas negociações entre as comunidades camponesas e o Estado visando as operações de desenvolvimento integrado (produção, comercialização, habitação, infraestrutura).

Iniciativas muito semelhantes tiveram lugar no Estado vizinho São Paulo, mas neste caso a Universidade Estadual de Campinas manteve convênios diretos com os Movimentos de Agricultores, sem passar por intermédio das estruturas do Estado.

Numerosos outros exemplos poderiam ser citados, de colaboração entre os meios científicos e os movimentos sociais. Esta colaboração constitui uma tradição com raízes profundas, sem a qual não é possível entender, no Brasil, as condições específicas nas quais se dão as relações entre o mundo da formação e da pesquisa, de um lado e de outro, da demanda social.

\section{A criação do Doutorado em Meio Ambiente e Desenvolvimento da Universidade Federal do Paraná}

A formação doutoral proposta pela Universidade Federal do Paraná é resultado de um trabalho de reflexão, iniciado em 1990, no contexto local da problemática meio ambiente/desenvolvimento, no Brasil e em particular no Paraná. Extrai sua substância nas múltiplas reflexões e propostas formuladas em outros países da região da América Latina/Caribe, a partir da tomada de consciência dos limites dos modelos de desenvolvimento existentes.

\section{O contexto internacional e regional}

Os objetivos desta formação universitária de pós-graduação estão em harmonia com as preocupações expostas, em ocasião dos diferentes trabalhos e reuniões preparatórias da Conferência das Nações Unidas sobre Meio Ambiente e Desenvolvimento, ocorrida no Rio de Janeiro em 1992 e propostas na Agenda 21. Coincidem, por sua vez, com as propostas do relatório Brundtland.

Estes trabalhos ressaltam alguns princípios e necessidades fundamentais.

- Antes de mais nada, a dimensão ambiental e a problemática do desenvolvimento. A primeira constitui parte integrante dos processos de desenvolvimento e por esta razão não pode ser tratada isoladamente.

- Em seguida, a fato de que a resolução dos problemas de meio ambiente e de desenvolvimento passa pela busca de soluções endógenas, isto é, que emanem da vontade livre da sociedade e que se apoiem na realidade socioeconômica, cultural e natural regional. Isto implica a promoção de uma pesquisa científica, visando a formação de competências para a implantação de planos nacionais de desenvolvimento, a produção e a gestão de tecnologia para um desenvolvimento sustentado. Isto supõe igualmente o reconhecimento da importância das especificidades culturais, especialmente no que se refere 
ao conhecimento das populações locais sobre o meio natural e sobre as modalidades de gestão e de utilização sustentável dos recursos.

- No que se refere à formação, a ênfase é colocada sobre o reforço da capacidade de constituição dos recursos humanos, em particular no domínio específico da gestão de recursos naturais.

Apesar de diversos centros de excelência em formação e pesquisa na América Latina e Caribe, estes estão distribuídos de forma desigual além de escassos programas de formação na perspectiva da interdisciplinaridade, principalmente nas áreas de desenvolvimento e da gestão integrada de recursos.

A Agenda 21, em seu capítulo 36, recomenda as universidades a jogar um papel de locomotiva na promoção ou na consolidação dos centros de excelência nacionais ou regionais em pesquisa interdisciplinar, em relação às ciências do meio ambiente e do desenvolvimento. No tocante à formação, a proposta é de uma profunda revisão dos cursos, a fim de garantir e desenvolver um enfoque interdisciplinar na formulação de diagnósticos relativos ao meio ambiente e ao desenvolvimento, levando em conta os aspectos socioculturais, econômicos, políticos e suas inter-relações. A formação ou a consolidação das redes universitárias em cada país ou a nível regional deve conduzir à promoção da pesquisa de forma cooperativa, ao intercâmbio e à difusão da informação.

Ademais, ao lado da formação universitária de $2{ }^{\circ} \mathrm{e}$ 3. ${ }^{\circ}$ ciclo (graduação e pós-graduação), a Agenda 21 apoia a implantação de programas de curta duração destinados à formação de profissionais do setor privado, de agentes de desenvolvimento e de técnicos, com a finalidade de fornecer à população e às comunidades locais os serviços necessários, em especial, os primeiros cuidados com o meio ambiente, especialmente nos meios urbano e rural desprotegidos.

\section{O contexto da iniciativa}

É necessário apresentar alguns aspectos históricos gerais da emergência da questão ambiental nesta região do Brasil. O Estado do Paraná que sofreu desde os anos 1940-60 uma dinâmica de frente pioneira, mostra de maneira exemplar os impactos produzidos pela coloni- zação das terras. A expansão da agricultura nas regiões férteis do Norte e do Oeste do Estado, a partir dos anos 40 , produziu a desaparição de $83 \%$ da cobertura vegetal existente. No final de 50 anos, as superfícies cobertas de florestas não representam mais do que $5 \%$ da superfície total - concentradas na região Centro-Sul e no litoral.

A agricultura, fundada no princípio da revolução verde, empregou sistemas técnicos inadaptados, que não levaram em conta as necessidades de reprodução dos recursos naturais e da fertilidade dos solos. As consequências foram desastrosas: apenas na região Noroeste, 1 milhão de hectares acusaram erosão, comprometendo as atividades agrícolas.

Este tipo de agricultura está na origem, também, do processo de acumulação da terra e do êxodo rural que é a sua consequência. No decênio 1970-80, ocorreu a desaparição de mais de 100.000 estabelecimentos agrícolas. O processo de acumulação fundiária atingiu particularmente os pequenos agricultores - posseiros, meeiros, pequenos proprietários -, que representam 93\% dos estabelecimentos desaparecidos. Isto se fez acompanhar da redução de 800.000 hectares de superfície consagrada às culturas alimentares e de um aumento de 2,7 milhões de hectares em culturas agroindustriais (cama de açúcar para combustível) e em culturas de exportação (sobretudo de soja).

Alguns fatos importantes da história recente contribuíram para a formação e a consciência ecológica neste Estado e à emergência de um contexto político original.

A - A mobilização contra a inundação das terras agrícolas pela barragem de Itaipu. O protesto iniciou em 1983, com reivindicações de natureza estética: a construção da barragem faria desaparecer as Sete Quedas do Iguaçu, conhecidas internacionalmente. Logo em seguida, o alagamento das terras agrícolas e a expulsão de 40.000 famílias camponesas evidenciaram os efeitos sociais deste canteiro de obras. Poderosos movimentos ecológicos, inspirados pela ADEA (Associação de Defesa Ambiental do Paraná), iniciados num contexto de proteção à natureza, foram seguidos por mobilizações dos sindicatos de trabalhadores rurais e pelo Movimento dos trabalhadores sem terra, auxiliados pela associação dos agrônomos do Estado do Paraná. Do protesto contra o desaparecimento das Sete Quedas, da expulsão dos agricultores de suas terras, à denúncia da poluição dos 
agrotóxicos, emerge uma reflexão crítica ao modelo agrícola da revolução verde. Essas lutas forneceram as condições para a colaboração entre os meios científicos, profissionais e os movimentos de origem popular.

B - Mobilização para a proteção da natureza e das culturas autóctones. Como prolongamento das lutas contra o desaparecimento das Sete Quedas do Iguaçu, constituíram-se movimentos ecologistas, cujo objetivo era a defesa dos últimos vestígios de um patrimônio natural e cultural: de início, pela defesa da Mata Atlântica e, posteriormente, contra a destruição da cultura Caiçara - uma das últimas populações da região deixada de lado pelo modelo de desenvolvimento da revolução verde. Em tomo destes objetivos, a Associação SOS Mata Atlântica, criada nos dois Estados vizinhos de São Paulo e Paraná, jogou um papel de proa na proteção do patrimônio natural e cultural e principalmente na implantação de uma legislação de proteção para a região.

C - O aparecimento de condições políticas favoráveis para a elaboração de uma política ambiental, ligada ao desenvolvimento local e regional. De 1983 a 1985, o poder local fica em mãos de uma geração de antigos líderes do movimento estudantil, de antigos exilados políticos na Europa ou na América Latina, de sindicalistas de longa data, de funcionários e de universitários democratas. Todos compartilhavam uma história de resistência à ditadura e uma sensibilidade para os problemas sociais derivados do desenvolvimento agrícola e rural: degradação dos solos, expulsão dos camponeses sob o efeito de grandes canteiros de obras ou como consequência da acumulação fundiária, êxodo rural.

Sob o efeito daquela influência, diferentes programas de pesquisa e de desenvolvimento foram empreendidos em diversos Institutos no Estado. O Paraná foi o primeiro Estado do Brasil a realizar consultas populares que originaram a elaboração do Programa de Meio Ambiente do Estado do Paraná (PEMA), em 1984. Um Comitê de Estado foi formado, reunindo diversas Secretarias de Estado: Agricultura, Educação, Interior, Planejamento, Saúde e Segurança Pública. Tinha por missão a aplicação de políticas concebidas para aquela finalidade.

A Secretaria de Estado da Agricultura e a Secretaria do Interior foram pioneiras nesta iniciativa. Defenderam uma visão crítica ao modelo vigente de desenvolvimento, identificando na abordagem exclusivamente tecnicista deste, a origem de um grande número de problemas ambientais. Algumas das principais iniciativas tomadas pela equipe, podem ser citadas.

- Criação, no Instituto Agronômico do Paraná, de um Programa de pesquisa sobre os Sistemas de Produção destinado a ponderar a abordagem dominante do modelo de desenvolvimento agrícola vigente.

- Lançamento de um programa para o desenvolvimento de uma agricultura alternativa, fundada na gestão integrada dos solos e das águas, na agroflorestal, no melhoramento das raças animais e das variedades vegetais rústicas, na tração animal como forma de energia alternativa, na luta biológica, no melhoramento das técnicas tradicionais (recuperação dos antigos moinhos). Essas opções técnicas foram acompanhadas de operações na área de produção de alimentos (hortas comunitárias, piscicultura rural, etc.) e de distribuição (mercados comunitários) e de proteção fundiária dos pequenos agricultores.

- Programas de economia dos recursos: construções comunitárias de redes de distribuição elétrica com materiais de baixo custo, abertura de fontes para abastecimento de água em micropoços.

- Controle rigoroso da poluição, programas de educação ambiental popular (água, ar, lixo).

Estas são algumas das iniciativas lançadas pela equipe durante o período no qual exerceu o poder público. Algumas delas alcançaram sucesso tendo sido adotadas em outros Estados do Brasil, outras conheceram o fracasso. O importante, para compreender a situação atual, é destacar que aqueles programas de ação estiveram na origem de uma dinâmica de colaboração entre universitários e pesquisadores, por um lado e por outro, de funcionários, técnicos e agentes de desenvolvimento (muitas vezes apoiados pelas respectivas associações profissionais).

Diante da instabilidade das estruturas políticas e para responder aos problemas levantados por uma colaboração, muitas vezes difícil, entre os diferentes parceiros que se encontravam no campo de ação, aparece a ideia de concentração em torno da Universidade, do esforço de formação a longo prazo, através do qual se constitua um capital humano adaptado aos desafios colocados pela necessária renovação das estratégias de desenvolvimento. 


\section{Ponto de partida da criação do Doutorado}

A Universidade Federal do Paraná é uma das universidades federais mais antigas do Brasil. Era identificada como conservadora em suas manifestações, privilegiando o desenvolvimento de polos tecnológicos, em detrimento das ciências humanas e sociais. O confronto com a problemática ambiental, como resposta a uma demanda social, intermediada pelo aparelho político, representou um desafio que implicou uma mudança no papel e na produção de um novo saber, capaz de responder às necessidades sociais, o que significa redefinir a prioridade nas relações entre as sociedades e os meios que são explorados por estas.

Excluindo o contexto sociopolítico do Paraná, um certo número de fatores externos também contribuiu para favorecer a mudança de visão sobre o novo engajamento da Universidade.

- Note-se, em primeiro lugar, que um movimento mais amplo produziu-se no Brasil, favorecendo o interesse das universidades pelos problemas ambientais. $\mathrm{O}$ ponto de partida foi um primeiro Seminário Nacional sobre a Universidade e o Meio Ambiente, que reuniu em 1986 dezenas de instituições universitárias. Uma das conclusões daquela reunião foi a implantação de cursos de pós-graduação em Meio Ambiente em universidades brasileiras. Desde então, desenvolveram-se alguns fóruns de discussão permanente. Foram abordados temas de reflexão sobre a necessidade de um enfoque interdisciplinar, sobre a necessidade de novos conceitos teóricos, sobre o papel social da produção do saber, sobre o conteúdo dos cursos. No último encontro, realizado em Belo Horizonte em 1992, foram sugeridas recomendações contidas na Carta de Belo Horizonte. Os trabalhos de seminários anuais publicados alimentaram e guiaram as discussões no seio das universidades interessadas na implantação de atividades de pesquisa, de formação e de difusão de conhecimentos na área ambiental.

- Por sua vez, a Universidade Federal do Paraná (UFPR) não pôde permanecer à margem da problemática local de destruição dos recursos naturais, evocados mais acima. As conjunturas locais e regionais sensibilizaram a nova direção democraticamente eleita, da mesma maneira que um grupo de professores engajados já em atividades de formação e de difusão junto às prefeituras, associações, sindicatos e aos movimentos populares.

A vontade expressa desta maneira, encontra um terreno de expressão favorável para uma colaboração estreita entre a UFPR e a Universidade Francesa Paris 7. Esta colaboração se organiza ao redor do projeto de criação de um curso de pós-graduação e de um Centro de Pesquisa Interdisciplinar, Formação e Difusão em Meio Ambiente e Desenvolvimento (NIMAD: Núcleo Interdisciplinar de Meio Ambiente e Desenvolvimento), criado em 1989 e que deve oferecer um quadro de colaboração aos professores da Universidade, oriundos de diferentes disciplinas. Contatos posteriores foram feitos com a Universidade de Bordeaux 2, que participa hoje das atividades de formação e de pesquisa ligadas ao projeto.

Repetimos aqui, pela sua importância, as etapas seguidas para cumprir esta primeira etapa do projeto.

- Consultar as autoridades universitárias sobre a importância que tal projeto de curso representava para a Universidade.

- Reunir os Departamentos de Ciências Humanas e Sociais, de Ciências Naturais e de Disciplinas técnicas, tendo em vista um trabalho preliminar, destinado a identificar o papel potencial e cada disciplina na abordagem das problemáticas ambientais.

- Formar um núcleo central de professores, ligados a diferentes disciplinas e encarregados de elaborar um pré-projeto, em suas dimensões práticas e teóricas.

- Organizar um seminário destinado a preencher um certo número de lacunas teóricas - em particular aquelas que estabelecem uma ligação entre meio ambiente e desenvolvimento, buscando definir também os avanços epistemológicos necessários para a implantação da interdisciplinaridade.

- Organizar um seminário de balanço das experiências relativas à formação' e à pesquisa em meio ambiente adquiridas pelas diferentes disciplinas sobre o tema.

Por essas diferentes etapas e a partir de um grupo bem motivado, tratava-se afinal de contas de associar os professores e seus departamentos, sublinhando o papel indispensável que deveria jogar cada uma das disciplinas - no plano da formação e da pesquisa. 
As reações da Instituição Universitária

A realização deste projeto não se fez sem encontrar obstáculos de diferentes espécies.

A - Alguns obstáculos de natureza científica. Alguns eram ligados à dificuldade sentida para separar o objeto de estudo "meio ambiente" do campo das disciplinas naturalistas (biologia, física, química, botânica, zoologia, etc.). Esta dificuldade se devia, por um lado, à impossibilidade, para estas disciplinas, de conceber o papel que as ciências sociais poderiam desempenhar na esfera da pesquisa. Porém, observou-se também que as disciplinas como a antropologia e a sociologia nem sempre percebiam, muito claramente, como elas poderiam aplicar seus métodos e suas problemáticas específicas quando aplicadas ao meio ambiente. Dessas incompreensões, derivava uma certa falta de interesse da parte dos professores e dos pesquisadores solicitados - o que se traduzia numa rotatividade elevada daqueles que estavam escalados para participar da organização do curso. A consequência foi a ausência de aprofundamento na reflexão teórica.

As diferenças de linguagem entre as disciplinas não facilitaram o intercâmbio e as discussões. Isto se deu particularmente no caso da comunicação entre as Ciências Humanas de um lado e as Ciências Naturais e as disciplinas de Engenharia, de outro. As prioridades de pesquisa, os métodos de trabalho, os esquemas de interpretação do real, da mesma forma que os níveis de análise não sendo os mesmos, de um grupo de disciplinas para outro, o diálogo que visava a definição de plataformas de trabalho encontrou uma certa dificuldade para se estabelecer.

A herança de estruturas universitárias, derivada do período anterior à democratização, também pesou. Assim, em Sociologia, a maioria dos professores manteve-se ausente, sem grande ligação com as atividades de pesquisa. A equipe mais dinâmica reduzia-se, assim, a um pequeno número de pesquisadores.

No final de contas, pela ausência de participação do Setor de Ciências Sociais e pela predominância do Setor das Ciências Físicas e Naturais, foi difícil, numa primeira etapa, definir um programa de pesquisa e de formação que pudesse aproximar o campo ambiental, bem como o das relações sociedade-natureza.

B - Outros obstáculos de natureza institucional. O NIMAD foi deliberadamente criado fora da estrutura de departamentos, a fim de promover a colaboração entre estes últimos e para poder garantir respostas à demanda social, sem ter que depender das divisões institucionais. Uma mesma estratégia foi aplicada em muitas outras universidades brasileiras (por ex.: Brasília, Campinas). Por isto, a constituição do NIMAD foi interpretada como uma ameaça para os territórios de poder, que alegavam o problema de divisão das disciplinas. Apareceram então reações defensivas, sob o argumento de que um doutorado não pode pretender-se interdisciplinar, à medida que deve ser o resultado de uma especialização. Esta argumentação prosseguia, afirmando o caráter de generalista dos doutores egressos do curso, cujo perfil estaria em contradição com o próprio caráter do doutorado que deve formar especialistas.

Às reações derivadas deste confronto de poder agregavam-se outros obstáculos de natureza administrativa: ausência de estruturas interdepartamentais, previstas nos regimentos; impossibilidade de jovens professores, não detentores do título de doutor, de participar de atividades de pesquisa e de formação de nível doutoral; estes, no entanto, são os mais dinâmicos e inovadores do corpo docente.

Somente ao final de uma longa maturação que estes diferentes obstáculos puderam ser superados. Muitos elementos foram importantes, neste sentido.

- A ação determinada de um pequeno núcleo de pessoas convencidas e que não se deixaram desencorajar, prosseguiram com a reflexão sobre o projeto e conseguiram fazer avançar na sua conceitualização.

- Uma explicitação dos objetivos do doutorado permitiu a resolução da contradição aparente, entre as exigências de especialização e as necessidades da interdisciplinaridade. Ficou bem estabelecido que a formação doutoral se dirige para especialistas que já receberam uma forte formação disciplinar e que vêm buscar os instrumentos teóricos e metodológicos necessários para lançar o diálogo, em torno dos problemas ambientais, com os cientistas de outras disciplinas. 
- A firme vontade da direção da universidade, que se esmerou a aplainar os obstáculos administrativos, quando necessário.

- A intervenção, durante as principais etapas, de parceiros de universidades francesas que puderam, ao mesmo tempo, jogar um papel de mediação e constituir uma garantia científica para o início do doutorado, para o qual estava prevista sua contribuição nas respectivas áreas de competência: formação e enquadramento das pesquisas.

\section{As estruturas politicas e as organizações técnicas do desenvolvimento e do meio ambiente}

O contexto político e social da tomada de consciência da questão ambiental no Paraná foi acima apresentado. No período de liberalização logo após o regime militar, a demanda social que se expressou de maneira explosiva dirigiu-se de maneira prioritária para as estruturas políticas locais - as quais vimos adotarem opções progressistas, convergindo no sentido de uma renovação de enfoque de desenvolvimento.

A - As circunstâncias de uma colaboração. $\mathrm{O}$ Estado do Paraná encontrou-se na linha de frente diante das reivindicações populares. Num primeiro momento, adotou uma posição de vanguarda frente a essas reivindicações: contribuiu para a sua organização. Em ocasião desta dinâmica, criou-se uma forma de consórcio entre a universidade e as estruturas político-administrativas. A instituição universitária aspirava ter acesso a uma utilidade social ampla - mais além da constituição e da renovação das elites dirigentes -, contribuindo para a formação de funcionários, técnicos, quadros, agentes de desenvolvimento, e por intermédio disto, para melhorar as políticas públicas relativas à gestão dos recursos naturais, no quadro de um planejamento do desenvolvimento rural e urbano.

Foi nestas bases que se estabeleceram as relações entre a Universidade Federal e o Estado do Paraná. Uma reunião conjunta, entre diversos departamentos da Universidade e das Secretarias de Estado da Educação, do Planejamento, da Agricultura, do Desenvolvimento Urbano e do Meio Ambiente foi organizada em presença do Vice-Governador e do Reitor da Universidade. Os representantes do Estado mostraram a necessidade de formação dos quadros do serviço público e da juventude. Manifestaram a necessidade em "especialistas-generalistas" cuja formação era concebida como um meio para promover a mudança, no interior das próprias estruturas político-administrativas. O desejo expressava-se, naquela ocasião, em ver nascer uma nova universidade, que fosse capaz de sistematizar conceitos e métodos necessários para tratar problemas complexos, impossíveis de resolver apenas com o auxílio do enfoque monodisciplinar.

Este confronto, através do aparelho de Estado, com o apelo de uma utilidade social - já identificado por um certo número de professores e pesquisadores conduziu ao reforço da dimensão do desenvolvimento na concepção do curso de formação e de pesquisa. Um terreno prioritário de ação foi definido, onde deveria ser exercida a atividade de Pesquisa-Desenvolvimento: trata-se da região litorânea que, tendo evitado até o presente o efeito de homogeneização da grande agricultura, representa um meio diversificado nos planos natural e socioeconômico. Pode-se encontrar no litoral um laboratório para o exercício prático da interdisciplinaridade e a produção de diagnósticos de realidades complexas.

B - Os pontos de tensão. Apesar de um acordo de conjunto sobre os grandes objetivos, a relação que se estabeleceu entre o Estado e a Universidade Federal do Paraná, em volta da problemática do meio ambiente e do desenvolvimento, a tensão não deixou de acompanhar esta aproximação.

Um ponto importante de desarmonia residiu nas diferenças de funcionamento das instituições: como conciliar uma instituição universitária até então conservadora, elitista, comprometida com uma ideia contestada do progresso, porém estável, com um Estado dinâmico, preocupado com a realidade social, porém instável uma vez que sofre frequentes remanejamentos políticos. Para atenuar a falta de dinamismo de certos setores da universidade, os quadros e os pesquisadores do Estado propuseram, para a condução da formação de pós-graduação em Meio Ambiente e Desenvolvimento, a constituição de um comitê paritário. A Universidade recusou esta proposta, uma vez que estava ligada à defesa de suas prerrogativas, em matéria de atribuição de diplomas. Um dos argumentos adiantados foi também - e aqui ressalta- 
-se as diferenças de estabilidade das instituições - que a Universidade não poderia colocar-se numa situação de dependência diante de instituições governamentais cujas opções tornavam-se prisioneiras de reviravoltas da vida política.

O conflito foi superado mediante a assinatura de um protocolo de intenções entre a Universidade e as Secretarias de Estado do Paraná envolvidas no projeto. Este documento estabelecia o papel de cada um dos parceiros, em vista dos seguintes objetivos:

- Formar cientistas, técnicos e funcionários que respondam às necessidades da Universidade, do Estado e das populações.

- Elaborar novos conhecimentos, métodos, técnicas que possam permitir a gestão e o planejamento de sistemas complexos.

- Conceber e gerar programas de desenvolvimento sustentado, fundados na utilização racional dos recursos renováveis e no respeito às populações que os exploram.

- Trabalhar para o desenvolvimento de uma rede universitária nacional sobre o Meio Ambiente e o Desenvolvimento, privilegiando, nesta colaboração, as universidades das regiões as mais desprotegidas.

\section{Conclusão}

Uma reflexão teórica e metodológica permite mostrar que a colaboração entre Ciências Humanas, Ciências da Natureza e disciplinas técnicas se coloca no centro do campo do conhecimento e da ação, que se estrutura em torno da noção de meio ambiente - e, mais especificamente, de desenvolvimento sustentável.

Mas uma tal interdisciplinaridade não pode ser decretada. Ela se constrói. A longo prazo, com dificuldade, por um trabalho de surdina para superar a lentidão que freia a evolução das estruturas de ensino e de pesquisa, os obstáculos que se opõem à colaboração entre os múltiplos parceiros (intelectuais, políticos, representantes do mundo econômico, responsáveis de movimentos populares) que estão envolvidos, de uma maneira ou outra, quando se trata de conceber, sobre bases científicas e sociais válidas, estratégias duradouras de desenvolvimento, para em seguida colocá-las em prática.

Uma pesquisa inovadora, a formação e a informação são os alicerces de uma dinâmica destinada a constituir os recursos humanos necessários para alcançar um tal objetivo. O exemplo do Brasil, e mais precisamente, o da experiência de criação do Doutorado em Meio Ambiente e Desenvolvimento na Universidade Federal do Paraná permitiu ilustrar, de maneira concreta, as condições nas quais as soluções podem ser buscadas para responder a essa necessidade.

Trata-se, evidentemente, de um caso entre muitos outros - na América Latina e em outros lados. O objeto da Conferência sobre as Cátedras UNESCO de desenvolvimento sustentado que ocorreu na Universidade Federal do Paraná de $1^{\circ}$ a 5 de julho de 1993 foi justamente o de permitir o confronto de experiências variadas, a fim de tentar extrair uma problemática comum, da mesma maneira que os princípios de ação concreta, na área de formação e de pesquisa.

O presente texto pretende ser uma contribuição ao debate. Após esta reunião, a Universidade Federal do Paraná foi contemplada com uma Cátedra da UNESCO para o Desenvolvimento Sustentável, recebendo assim um poderoso estímulo, devido a seu esforço para promover uma nova abordagem da pesquisa e da formação no campo de meio ambiente e desenvolvimento. 


\section{Referências}

Brundtland, G. H. Notre avenir à tous. Quebec: Edition du Fleuve, 1988. Version anglaise: Our Common Futur, Oxford University Press, 1987.

Dobremez, J.-F.; Jollivet, M.; Hubert, B; Raynaut, Cl. Pour une pratique de l'interdisciplinarité Sciences de la Nature-Sciences de l'Homme: Leçons de 10 années d'expériences au CNRS, Centre National de La Recherche Scientifique, Paris, 1990.

Godelier, M. L'idéel et le materiel. Fayard, 1984.

IUCN. Stratégie Mondiale de la Conservation. Ed. IUCN/ MNUE/WWF, 1980.

Jacobs, P.; Munro, D. (Eds.). Sustainable and equitable development: an emerging paradigm. Conservation with equity: strategies for sustainable development. UK, 1987.
Jollivet, M.; Pavé, A. Questions et perspectives pour la recherché. Lettre du programmes Environnement, CNRS, n. 6, Mai 1992.

Jollivet, M.; Pavé, A. L'environnement: un champ de recherché en formation. Natures, Sciences, Societés, 1(1), 1993.

Pezzey, J. Definitions of Sustainability - Appendix, Ed. UK CEED, 1989.

Sachs, I. Stratégies de l'écodevelopment. Paris: Les Editions Ouvrières, 1980. p. 12.

Vattimo, G. "L'éducation contemporaine, entre épistémologie et herméneutique". In: Entre savoirs. L'interdisciplinarité en acte: enjeux, obstacles, resultants. Érès, 1992. 